\title{
Technical Type Evaluation and Approval for Equipment Subject to Metrological Control in Brazil: Main Aspects and Guidelines
}

\author{
Téo Revoredo' (1D) orcid.org/0000-0002-9794-5769 \\ ${ }^{1}$ Faculty of Engineering, State University of Rio de Janeiro, Rio de Janeiro, Brazil, \\ E-mail do autor principal: Téo Revoredo teorevoredo@uerj.br
}

\section{Resumo}

\begin{abstract}
A aprovação de modelo de um instrumento de medição sujeito à controle metrológico é o ato pelo qual um instituto nacional de metrologia reconhece a sua capacidade de atender a todos os requisitos regulatórios aplicáveis e gerar resultados confiáveis. Ela é obtida após um procedimento de avaliação que envolve análise documental e testes de desempenho. Embora geralmente conhecido, uma vez que é conceito aplicável em todo o mundo e, apesar das recentes ações do INMETRO para melhorar sua eficiência, o processo de apreciação técnica de modelo gera dúvidas, pois abrange um grande número de requisitos apresentados em diferentes normas e regulamentos, alguns incomuns em outros países. As dúvidas relacionadas ao processo, adicionadas à falta de conhecimento por parte do requerente, dificulta boas estimativas de custo e tempo, especialmente para empresas estrangeiras, levando à atrasos ou mesmo à não conclusão de processos. Assim, este trabalho apresenta os requisitos e as diretrizes gerais para realizar a aprovação de modelo de um ou mais instrumentos no Brasil, visando ser uma referência rápida e sólida à possíveis requerentes, especialmente empresas estrangeiras. Uma família hipotética de medidores de vazão de líquidos é utilizada para apresentar as diretrizes e estimativas aproximadas de custos.
\end{abstract}

Palavras-Chave: Aprovação de modelo; Metrologia legal; Medidores de vazão;

\section{Abstract}

Type approval of a measuring instrument subject to metrological control is the act through which a national metrology institute recognizes its capabilities to meet all applicable regulatory requirements and provide reliable results. It is accomplished after an evaluation procedure that mainly involves analysis of documents and performance tests. Although generally well known since it is applicable worldwide, and despite Inmetro's recent actions to improve its efficiency, the ATM process usually creates doubts in Brazil as it encompasses a great number of requirements presented in different rulings, some of which are uncommon in other countries. The doubts related to the ATM process, in addition to the lack of knowledge of the applicant, often makes it hard to have good estimates of cost and time to accomplish a type approval before it is requested, especially for foreign companies, and commonly lead to great delayed or inconclusive processes. Thus, this paper presents the general requirements and guidelines to accomplish the Brazilian type approval of one or more instruments aiming to be a quick and solid reference to possible applicants, especially companies from abroad. $A$ hypothetical family of liquid flow meters is used as reference to present the guidelines and rough estimates of costs.

Key words: Type approval; Technical type assessment; Metrological control. 


\section{Definitions}

Certified translation - Translation made by sworn public translator, whose signature is recognized in a notary's office in Brazil and thus possesses official and legal validity before public organizations and institutions.

Consularization - Legalization of a copy of a document with the embassy or consulate of Brazil in the country of the document's source.

Sample unit - One unit of the equipment under type approval assessment that is submitted to Inmetro or third party laboratory for evaluation and tests.

\section{Introduction}

The type approval of an equipment subject to metrological control is defined as the act through which

the Brazilian national metrology institute (Inmetro) recognizes that a measuring instrument, a materialized measurement or some of their parts is/are able to meet all applicable regulatory requirements and be used to provide reliable results. All measurement equipment or materialized measures, manufactured either in Brazil or abroad, which possess relevant metrological technical regulation (RTM) must have type approval before they are placed in the Brazilian market, for either commercialization or use [1].

The type approval of an equipment is accomplished after an evaluation procedure, named technical type evaluation (ATM, from Apreciação Técnica de Modelo, in Portuguese) which consists of an evaluation of the available documentation, visual and dimensional inspections and tests/assays in one or more models of the equipment, as defined in the metrological technical regulations. The type approval is a diploma of a legal nature [2] and is Inmetro's responsibility, through its Legal Metrology Board (DIMEL), to execute the technical type evaluation.

Generally speaking, the ATM procedure is well known worldwide, as it is a concept applicable by many countries and that in most of them is based on international recommendations such as the ones from the International Organization of Legal Metrology (OIML) [3]. Despite that, and as simples as it may appear, the Brazilian ATM process involves many requirements (not only technical) that should be thoughtfully met. They are specified in different rulings and are initially general by nature, as they encompass different types of equipment with diverse technologies and/or principle of operation. In addition, the available documentation and/or eventual international certificates and test reports for an instrument or family of instruments is different from one equipment to another and adds difficulties to the establishment of which and how many documents should be provided when filing for an ATM process, such as: Which documents should be consularized and certified translated, which could be free translated, which do not need to be submitted, which drawings should be provided and in what format, etc. Furthermore, the applicable assays that should be realized, the criteria to be met and the laboratories capable of performing them are an important part of the ATM process and should be specified to each type of equipment subject to ATM. The detailed list of assays is not clearly found on the rulings as they are general by nature. They are defined by Inmetro's technicians during the ATM process based on the current regulation and applicable technical recommendations, in addition to experience.

All of these aspects of the ATM process often make it hard to have good estimates (in advance to the formal ATM request) of cost and time to accomplish the type approval of an equipment, especially for foreign companies. The lack of knowledge of the paperwork involved in the process, as well as the doubths that arise from it, makes it hard to these companies to well predict the time, cost and effort that should be put in type approving an instrument in Brazil, and thus well plan their strategy for the Brazilian markets that depend on such approval. Examples of such doubths are: The number of sample units that would be required to be tested (to represent a family of instruments, for example), the most likely specifications of such instruments, the locations to which they should be sent for tests, the required assays and the estimated time for their execution, etc. It is not uncommon to have greatly 
delayed, unconcluded or even not started ATM processes due to this great number of doubths and the costs they incur.

It is worth noting that Inmetro has been working to reduce the duration of ATM processes and improve their efficiency, focusing in lowering internal financial and human resources [4]. As an example, one may cite the online system which allows registration, processing and monitoring of the ATM processes, which is one of the results of such efforts and was meant to reduce time in communications between applicant and Inmetro, as well as facilitate the submission of documents, among other matters. Despite the improvements made, from the applicant's point of view, and especially for foreign companies, most of the doubts aforementioned remain regarding the specificities of the process for certain equipment.

Based on this scenario, this paper intends to summarize the general requirements of an ATM process and provide the guidelines to accomplish the Brazilian metrological type approval for one or more instruments.
A hypothetical family of ultra-sonic liquid flow meters to measure petroleum and its derivatives as well as anhydrous and hydrated alcohol is considered as basis the requirements of ATM process and the main sources of cost to its realization.

The paper is structured as follows: Section 3 presents the general overview of the Brazilian ATM process, to describe the requirements of an ATM process and the main sources of cost to its realization.

Section 4 provides detailed guidelines of the process and Section 5 presents the description of the costs that may incur during the ATM process as well as a rough estimate for them. In Section 6 conclusions are drawn.

\section{Brazilian ATM Process Overview}

Figure 1 presents a general overview of the type approval evaluation process, for which general description is provided in the next section [5], [6].

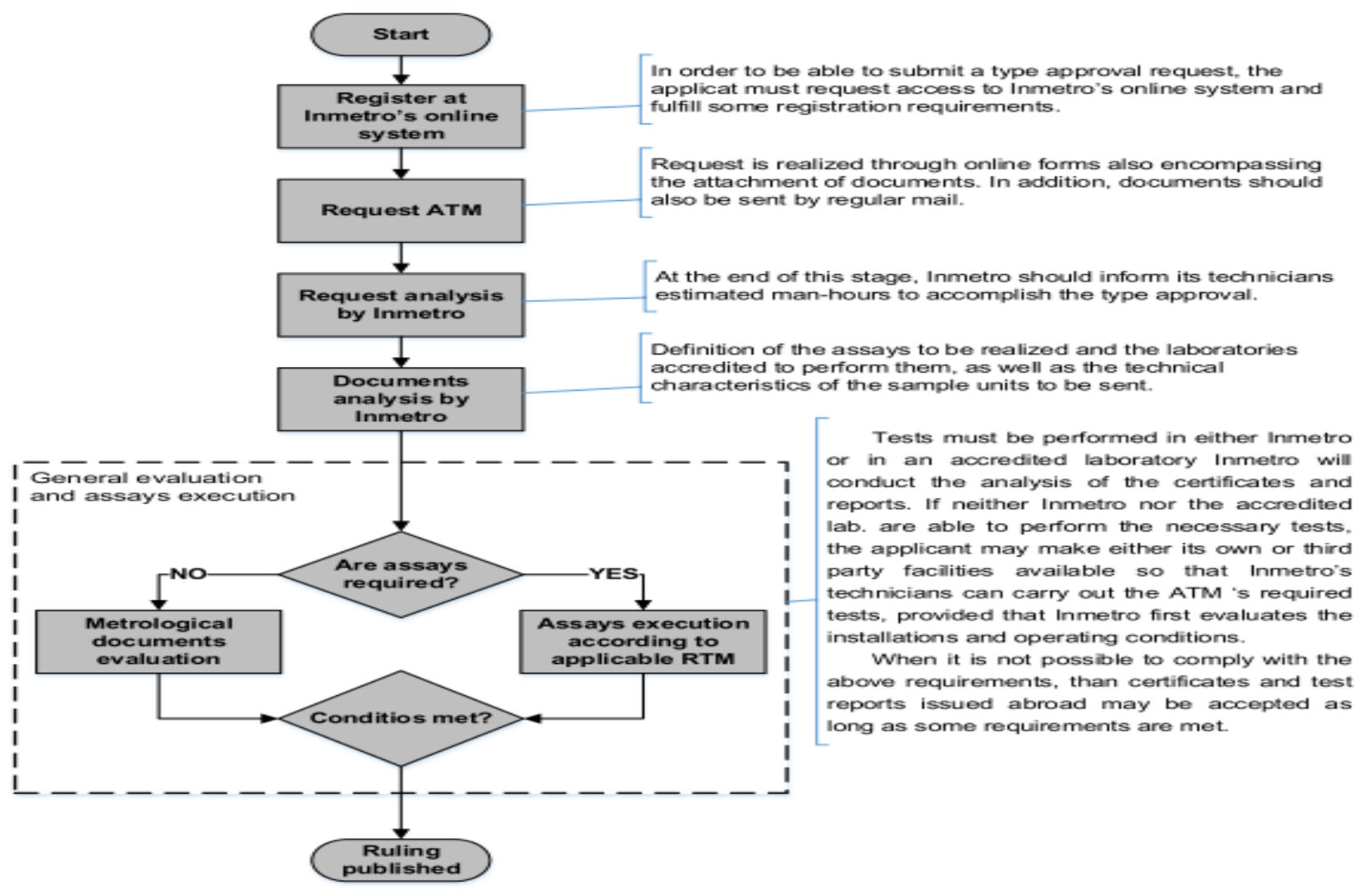

Figure 1: General overview of ATM process. 


\section{Guidelines}

The general requirements to be met during the ATM process of an equipment are described in Ruling 484/2003 [6]. The main ones are presented in the next subsections. In this work, a hypothetical family of liquid ultra-sonic flow meters applicable to measure petroleum and its derivatives as well as anhydrous and hydrated alcohol is considered as an example to describe all involved aspects of the type approval process. When considering liquid flow meters based on different technologies, the same RTM here used as reference should be considered, although it might imply in different specific criteria. Furthermore, if the equipment under ATM is not encompassed in the class defined above, then different RTM should be applicable.

\subsection{The need for a Type Approval Request}

It is up to Inmetro to define, by means of specific normative acts, which instruments require regulation for type approval. Regarding liquid flowmeters used to measure petroleum and its derivatives as well as anhydrous and hydrated alcohol, the current RTM is annex to Ruling 064/2003 [7].

\subsection{Registration and Type Approval Request}

In order to file for an ATM, the first step the applicant must take (see Figure 1 ) is to request access to the Inmetro's online system through which the type approval process will be conducted (and monitored). The login request should be realized according to the procedure outlined in Inmetro's directives [5].

Once registered at the online system, the applicant may file for an ATM. The following documents should be submitted at this point in order to request a type approval evaluation (as outlined in Inmetro's directives [5] and in Ruling 064/2003 [7]):

- Administrative documents:

a) Current consolidated articles of incorporation, bylaws or articles of association, all duly registered by competent party;

b) Proof of registration in the Brazilian General Taxpayer Registry (CNPJ);

c) Proof of registration in the Brazilian register of taxpayers (state and/or municipal), if any, pertinent to the field of activity and compatible with the object of the ATM request;

d) Proof of regularity with the national treasury and the active debt of the federal, state and municipal

e) Brazilian spheres of government;

f) Proof of regularity regarding social security and the guarantee fund for length of service (FGTS);

g) Letter of authorization from the manufacturer, in the case that the applicant is not the manufacturer.

- Technical documents:

a) Form FOR-DIMEL-207 [8] dulycompleted;

b) Form FOR-DIMEL-038 [9] dulycompleted;

c) General description outlining the instrument's main characteristics and principle of operation;

d) Detailed drawings according to Inmetro's template [10]. Drawings should include: Seals and metrological stamps position as well as regulatory inscriptions detail;

e) List of components and their materials when they are metrologically relevant;

f) Mounting scheme and identification of the different components

g) Functional description of main electroni components, including logic diagram; 
h) Certificate of origin, sales leaflets, photograph and documents intended for the user, including instructions for installation and preparation of the instrument in view of its use as well as user's, operation, maintenance and repair manuals;

i) Publications describing the principle of operation of the instrument or its main devices;

j) Test reports or calibration certificate, previously performed by other laboratories;

k) Eventual additional documents based on the applicable RTM.

All files submitted online should be identified according to the criteria presented in Inmetro's directives [5]. In addition to the online submission, all administrative documents must also be sent by regular mail to Inmetro.

It is important to point out that the list of technical documents presented above is based on current regulation which is general by nature. A detailed evaluation often reveals many redundancies between documents, depending on the equipment under assessment, which makes sense when one needs to encompass under the scope of a ruling different equipment with different types of documentation. In addition, not all documents are applicable to every type of instrument. It is usually possible to lessen the number of required documents and especially the need for translating most of them at submission and later in the ATM process. Such possibility should be evaluated in coordination with Inmetro when (if) the type approval request is filed.

If a company is able to provide all administrative documents listed above (If the company is duly established in Brazil), then it may be the applicant to the ATM process and the type approval ruling, when published, would encompass only its name. For instance, if the manufacturer of an equipment is an internationally based company, but also legally established in Brazil, it may file an ATM process in its name, having no need to file it through another company such as a representative. Even so, if the applicant would require assistance to carry out the ATM process, it would be possible to name a consulting company or person to do so. This could be achieved by specifying the consultancy company's or person's contact in Inmetro's online system when starting the process.

The test reports and certificates submitted at this point may not yet be certified translated. They will have to be, thought, when (if) Inmetro confirms that there will be equipment approved by using the international laboratories test reports instead of performing the assays in Brazil (see Section 4.4 for details). If that is so, then there will also be the need to accomplish the consularization of such documents, before submitting them to a certified translator.

It is worth noting that if an equipment has been approved in the past, one may file for a modification of the current type approval administrative ruling instead of requesting a new one [11]. In such case, the changes/upgrades made to the equipment would be evaluated by Inmetro and might be considered as applicable for an updated version of the current ruling, instead of requiring a new type approval process. Assays would probably be requested anyway, though, depending on the new capabilities of the equipment, to validate the new features. In addition, it is important to notice that a type approval is granted to a specific applicant, which means that the request to modify the current type approval ruling would have to be done by the former applicant and the updated ruling would also have its name. For instance, if an international company had a Brazilian type approval ruling issued for an equipment it manufactures using its former representative as applicant, an updated ruling would have to be requested by the latter and the new ruling would encompass its name as well. When requested by different applicants, even identical instruments, manufactured by the same company, should be subject to separate type approval processes. 


\subsection{Request Evaluation}

Once all documents are submitted, Inmetro will proceed with the type approval request evaluation according to the criteria presented in Ruling 484/2003 [6]. When the request is approved, Inmetro should inform the estimates of cost (based on law $12.249 / 2010$ [12]) and time needed for the execution of the service.

\subsection{Verifications and Assays}

\subsubsection{Administrative Procedures}

The following administrative procedures shall be followed when realizing the assays required by the ATM process:

- The applicant/manufacturer must submit the number of sample units required by Inmetro;

- Inmetro shall inform the applicant of the procedures to be followed, including which tests need to be performed as well as the laboratories capable of performing them, in compliance with Ruling 484/2003 [6];

- The applicant can request the tests to be performed at the laboratory which he chooses only after the commencement of the ATM process;

- Depending on the instrument to be tested, Inmetro must establish the necessary procedures to ensure the identity and integrity of the instruments submitted;

- Once all assays are completed, Inmetro shall issue a report, containing the list of tests performed and the results obtained, which shall be part of the ATM administrative process;

- In the case of tests carried out abroad, reports issued by a competent metrological body may be accepted before the start of the ATM process, if the criteria provided in Section 4.4 .2 are met.

\subsubsection{General Evaluation and Assays Execution}

The tests required in the RTM of the equipment subject to ATM must be performed either in Inmetro's laboratory or in a laboratory accredited by Inmetro's General Coordination of Accreditation (CGCRE) [13] for the applicable scope. It is up to Inmetro to conduct the analysis of the certificates and reports issued by a Cgcre/Inmetro accredited laboratory. Reports issued by one or more laboratories linked to the applicant/manufacturer will not be accepted, even if they are accredited by Cgcre/Inmetro, with the following exception: If neither Inmetro nor an accredited laboratory are able to perform the necessary tests, the applicant may make either its own or third party facilities available so that Inmetro's technicians can carry out the ATM 's required tests, provided that Inmetro first evaluates the installations and operating conditions of the infrastructure and find them appropriate.

When it is not possible to comply with the above requirements, then certificates and test reports issued abroad may be accepted as long as all of the following are met [6]:

1. Test report submitted for type approval was part of other ATM process which resulted in the equipment's approval realized by a competent metrological organization;

2. The assays carried out prove the compliance with the updated version of the RTM;

3. Copies of the certificates and reports issued abroad are duly consularized and accompanied by certified translation to Portuguese language.

\subsubsection{Type of Verifications and Assays}

Ruling 064/2003 [7] was issued by Inmetro in April 11th 2003 aiming to establish metrological control over all measurement systems encompassed by ANP/Inmetro Joint 
Ruling No. 001 issued in June 19th 2000, which was revised in 2013 [14]. Based on recommendation 117 of the International Organization of Legal Metrology (OIML) [15], Ruling 064/2003 establishes technical and metrological requirements applicable to measurement systems equipped with fluid meters, used in the measurement of petroleum, its liquid derivatives, alcohol anhydrous and hydrated alcohol fuel.

Although Ruling 064/2003 presents general requirements, in the sense that it encompasses different types of flow measurements systems, it is currently the applicable Brazilian regulation to proceed with type approval for ultra-sonic flow meters (which are the type of flow meters here considered as an example). It is, though, important to notice that Ruling 064/2003 states that "The Legal Metrology Board of Inmetro may, in addition to the technical metrological requirements presented in this ruling, establish other requirements that it deems necessary during the process of implementation of metrological control of oil metering systems, its liquid derivatives, anhydrous alcohol and hydrous alcohol fuel".

The general tests and verifications listed as requirements in the above RTM are used as basis for Inmetro's technicians to determine the specific tests required for each instrument under type approval evaluation. Based on Inmetro's documentation, the tests that could be demanded during the process of type approval for the ultra-sonic liquid flow meters family here hypothetically considered are listed below:

1. Visual inspection: Aims to verify the compliance of meter characteristics with current regulation and with the documentation of the equipment;

2. Dimensional verification: Aims to verify that all dimensions of the meter comply with current regulation and with the documentation of the equipment;

3. Performance assays: Aims to verify compliance with metrological requirements, that is, to attest that errors and uncertainties are within the specifications of the current regulation;
4. Climatic assays: Aims to verify compliance of the flow meter performance under different climatic conditions;

5. Electric and magnetic assays: Aims to validate the performance of the flow meter electronic components;

6. Mechanical assays: Aims to verify compliance of the meter's performance to metrological requirements when submitted to shock and vibration.

The required tests for a specific type approval process are only defined and informed by Inmetro after the type approval request has been evaluated by the Legal Metrology Board. As already discussed in Section 4.4.2, the general guideline regarding assays is that they should be realized in Brazilian facilities, no matter what have already been accomplished in laboratories abroad, except when there is no laboratory in Brazil capable of performing them. In the latter case, certificates and test reports from abroad may be used to approve the instrument in Brazil.

\subsubsection{Visual Inspection}

Visual inspection is a simple procedure that aims to verify the compliance of a meter's characteristics with its available documentation as well as with current regulation. It is a procedure that may be realized by the laboratory which would test the performance of the meter, or by another specialized company or professional.

\subsubsection{Dimensional Verification}

Dimensional verification is a fairly simple procedure that aims to verify the compliance of the meter's dimensions with its available documentation (especially drawings) as well as with current regulation. It is a procedure that can usually be realized by the laboratory which would test the performance of the meter, or by another specialized company or professional. 


\subsubsection{Performance Assays}

The performance assays that are usually recommended for liquid flow meters such as the ones here considered and thus may be demanded by Inmetro during the ATM process are the following:

1. Sealing assay;

2. Error curve determination assay;

3. Repeatability assay;

4. Accelerated wear test;

5. Post-wear error curve assay;

6. Disturbance test.

As an example, the following subsection provides a simple description of a general procedure to be followed to perform the performance assays in ultra-sonic flow liquid meters, aiming to provide an idea of the effort involved. The procedure is based on OIML recommendations.

\subsection{General Procedure}

The procedure to be realized to execute the performance assays can be roughly described as follows:

1. Mandatory inscriptions inspection
a. Survey of mandatory inscriptions, according to item 8.1 of Ruling 064/2003 [7].

2. Error curve determination

a. A survey of the error curve shall be carried out in order to verify the limits of maximum allowable errors;

b. The errors shall be determined at the following nominal flow values:

i. Maximum (Qmax);

ii. Minimum (Qmin) and

iii. At least four intermediate values. At every flow rate tested, the errors must be determined at least three times. They must not exceed the maximum allowable one.
3. Repeatability

a. Based on Ruling 064/2003 [7], the repeatability error of a flow meter is the difference between the largest and the smallest errors resulting from a series of successive measurements of the same quantity, carried out under the same conditions. Such error shall be equal to or greater than five times the minimum measurable quantity and such difference shall not be greater than $0,12 \%$. This criterion applies to all test points described in item $2 b$ above.

4. Wear test

a. Consists of placing the meter in operation with flow rate between 0,8Qmax and Qmax for either one period or several periods of time totalizing 100 hours of operation, so that the test is performed within a maximum period of 30 days. The wear test shall be performed with either water or lubricating oil.

5. Post-wear error curve determination

a. Once the wear test is concluded, the meter should be subjected to an accuracy test one more time. The same flow rates defined in item 2 above should be considered. The results obtained should be compared to the results accomplished before the wear test. The deviations must remain within the limits specified for the class of meter under test without any adjustment or correction.

There are laboratories in Brazil capable of performing tests such as described above on meters with diameters ranging from less than $4^{\prime \prime}$ up to at least $16^{\prime \prime}$. Thus, it is likely that performance assays would be requested if an ATM procedure were to take place on the flow meters here hypothetically considered. It is 
worth pointing out, though, that there might be no laboratory accredited to perform the specific tests as described at the applicable RTM. In such case, an Inmetro technician would have to witness the tests.

In cases where the type approval is requested for a family of meters instead of only a specific model, it is usually required that tests are carried out in meters possessing different diameters, typically the smallest, the greatest and an intermediate one, although testing only one meter is also a possibility. Consider the following example: A flow meter family with diameters ranging from 2" to 40" which has already been tested in laboratories outside Brazil that complies with the requirements listed in Section 4.4.2.

Considering the assumptions above, one of the three options below would be most likely to happen regarding performance assays (1 - Most probable, 3 - Less probable):

1. Sample units with 2 " and 16 " should be required for tests and meters with greater diameters would be approved based on the available international reports;

2. Sample units with $2^{\prime \prime}, 8^{\prime \prime}$ and $16^{\prime \prime}$ should be required for tests and meters with greater diameters would be approved based on the available international reports;

3. One single sample unit with either 2 ", 6 " or 8 " should be required for tests and all other meter diameters would be approved based on the available international reports;

In any case, test reports for all meters which diameters are greater than those that Brazilian labs can test would need to be consularized and certified translated.

For reference, a list of laboratories that could be consulted to perform not only performance, but any other required assay may be found in Inmetro's CGCRE website [13], under the search engine for currently accredited laboratories to the Brazilian Calibration Network (RBC) and to the Brazilian Network of Assays Laboratories (RBLE). It is worth noting that currently other laboratories may be accepted, as long as all standards used are duly traceable.

\subsubsection{Climatic Assays}

The required climatic assays for liquid ultra-sonic flow meters are listed below:

1. Dry heat;

2. Damp heat;

3. Cold

As an example, the next subsection provides a simplified description of the procedure to carry through the climatic assays for flow meters such as the ones considered in this work.

\subsection{General Procedure}

Climatic tests must be performed inside a climatic chamber with controlled temperature and humidity. The tests would consider severity level $C$ as specified in Annex $A$ of [15]. The procedure to be followed could be roughly summarized as follows:

1. Dry heat test, one cycle

a. Initial reference temperature of $(20 \pm 1)^{\circ} \mathrm{C}$;

b. Once temperature is stabilized, the meter should be exposed to $(55 \pm 1)^{\circ} \mathrm{C}$ for 2 hours;

c. Following item $b$, the meter must return to the reference temperature of $(20 \pm 1)^{\circ} \mathrm{C}$.

2. Cold test, one cycle

a. Initial reference temperature of $(20 \pm 1)^{\circ} \mathrm{C}$;

b. Once temperature is stabilized, the meter should be exposed to $(-25 \pm 1)^{\circ} \mathrm{C}$ for 2 hours;

c. Following item $b$, the meter must return to the reference temperature of $(20 \pm 1)^{\circ} \mathrm{C}$.

3. Cyclic wet heat test, two cycles

a. Initial reference temperature of $(20 \pm 1)^{\circ} \mathrm{C}$;

b. Once temperature is stabilized, the meter should be exposed to $(55 \pm 1)^{\circ} \mathrm{C}$ and 
relative humidity greater than 93\% during 24 hours;

c. Following item $b$, the meter must return to the reference temperature of $(20 \pm 1)^{\circ} \mathrm{C}$.

4. Error curve determination after the climatic tests

a. After the climatic test, the meter shall once more be subjected to an accuracy test at the same flow rates as defined in the performance assay.

\subsubsection{Electric and Magnetic Assays}

The usually required electric and magnetic assays for liquid ultra-sonic flow meters are listed below:

1. $A C$ and/or DC Mains voltage variation;

2. Electrostatic discharge (ESD);

3. Electromagnetic susceptibility;

4. Burst on AC and DC mains;

5. Mains power voltage dips, short interruptions and

6. Voltage variations

The procedures to perform such tests can be found on [15] and the related standards from the International Electrotechnical Commission (IEC) [16].

\subsubsection{Mechanical Assays}

The required mechanical assays for liquid ultrasonic flowmeters are listed below:

1. Random vibrations;

2. Mechanical shock.

The procedures to perform such tests can be found on the OIML recommendations [15].

\section{Costs and Terms Considerations}

Costs and terms associated to the ATM process may become quite large, especially when there is equipment importation involved. Good estimates of all costs that might incur when proceeding with an ATM request are crucial to the decision making of a manufacturer (or representative or other company involved) regarding not only the type approval itself, but to every other business that would depend on it. Experience shows that some costs are sometimes neglected due to lack of knowledge. For example, the need to certify translate certain documents is not always clear to international companies and the cost involved can be quite substantial in the process.

A rough idea of how costly the ATM process can be is here provided. All costs were obtained through budgetary quotations from Brazilian certification companies and test laboratories, as well as Inmetro's website, and should serve only as reference. One should bear in mind that the estimates were done based on the hypothetical liquid flow meters family here considered, and the assumptions presented so far. The estimates were obtained in August 2017 using an exchange rate of 1 USD $=3,16$ Reais.

The costs associated with an ATM approval process may be classified into four main categories as follows:

1. Documents translation;

2. Inmetro man-hours;

3. Assays;

4. Certification consultancy.

\subsection{Documents Translations}

All required documents that should encompass the type approval submission must be in Portuguese language. In addition, test reports and certificates, when applicable, must be translated by certified translator. Optional documents may be in English. Table 1 presents an idea of cost associated with free and certified translation.

Table 1: Cost estimates for documents translation.

\begin{tabular}{lll}
$\begin{array}{l}\text { Type of } \\
\text { translation }\end{array}$ & $\begin{array}{l}\text { Cost per page } \\
\mathbf{( 2 0 0 0} \\
\text { characters) }\end{array}$ & Remarks \\
\hline Free & 7 USD & Rough estimate \\
\hline Certified & 35 USD & Rough estimate \\
\hline
\end{tabular}




\subsection{Inmetro Man-Hours}

All ATM services executed by Inmetro
should be covered by the applicant/manufacturer. The costs refer to the hours of service required for the technical evaluation of the equipment as well as the hours spent with the publication of the type approval ruling. There are other costs that may eventually occur depending on each process, such as reimbursement of travel expenses, equipment rental, additional service hours needed to accompany assays, etc.

The number of hours of service depends on the type of instrument and may be consulted in Inmetro's website [17]. The cost of one man-hour is established by Law [12] and is currently about 90 USD. When an equipment model is approved, about 90 USD are added to encompass the publication of each ruling that may result from the process.

In case of suspension of the process due to either failure, request from the applicant, or any other reason, the costs charged will be related to the services actually performed until the closing of the process. Payment to Inmetro are due 30 days after the ATM process is finished.

Table 2 presents a rough estimate of the cost related to Inmetro's man-hours associated to the ATM process of an ultrasonic liquid flow meter. The estimates are based on the average man-hours spent for the evaluation of one meter. If more than one sample unit is requested, than Inmetro's cost will be higher.

Table 2 takes into account neither travel expenses nor service hours due to assay accompaniment that may occur.

Table 2: Inmetro's cost estimate.

\begin{tabular}{lll} 
Man-hours & $\begin{array}{l}\text { Cost per } \\
\text { hour }\end{array}$ & Total cost \\
\hline 58 & 90 USD & 5220 USD \\
\hline
\end{tabular}

The man-hours presented in Table 2 are distributed along the duration of the type approval process which averagely takes about 8 months to be completed, disregarding time spent in importing and transporting sample units for tests. Time spent on assays are considered in this estimate, although it is an approximate one since it strongly depends not only on the type of tests to be realized, but also in the availability of the laboratories at the time the tests are requested.

\subsection{Verifications and Assays}

\subsubsection{Visual Inspection}

The visual inspection cost estimate here presented is based on man-hours spent. Table 3 presents an estimate of cost for the visual inspection of one ultra-sonic flow meter, including report emission.

Table 3: Estimated man-hours and cost for visual inspection of one ultra-sonic flow meter.

\begin{tabular}{lll} 
Man-hours & Cost per hour & Total cost \\
\hline 6 & 90 USD & 540 USD \\
\hline
\end{tabular}

\subsubsection{Dimensional Verification}

The dimensional verification cost estimate here presented is based on man-hours spent. Table 4 presents an estimate of cost for the inspection of one ultra-sonic flow meter, including report emission.

Table 4: Estimated man-hours and cost for dimensional verification of one ultra-sonic flow meter.

\begin{tabular}{ccc} 
Man-hours & Cost per hour & Total cost \\
\hline 8 & 90 USD & 720 USD \\
\hline
\end{tabular}

\subsubsection{Performance Assays}

All costs related to the realization of the required assays must be covered by the applicant/manufacturer. Table 5 presents a rough estimate of the costs that may incur due to the realization of the performance assays. It is an estimate for the realization of assay in one 10-inch diameter flow meter and do not encompass shipping or importation expenses. 
Table 5: Meter performance assay cost estimate.

$$
\text { Assay Rough cost }
$$

Performace 15000 USD

The estimated term to complete the electric and magnetic assays for one meter is about 2 days. In case there is the need to repeat the assay, one should consider an additional cost of about 1000 USD per day. This period of time begins when the meter is received by the laboratory and lasts until it has been prepared to be shipped out, after all required tests have been concluded.

The estimated term to complete the performance assay for one meter is about 35 days. This period of time begins when the meter is received by the laboratory and lasts until the laboratory has prepared it to be shipped out, after completing all required tests. However, it is important to notice that there is usually a waiting period of averagely 30 days after the test has been requested to the laboratory and the date it actually starts.

\subsubsection{Climatic Assays}

Table 6 presents a rough estimate of the costs to realize the climatic assays listed in Section 4.4.3.4 The cost presented is an estimate for the realization of assay in one flow meter and do not encompass shipping or importation expenses.

Table 6: Climatic assays cost estimate.

\begin{tabular}{cc} 
Assay & Rough cost \\
\hline Climatic & 6000 USD \\
\hline
\end{tabular}

The estimated term to complete the climatic assay for one meter is about 20 days. This period of time begins when the meter is received by the laboratory and lasts until the laboratory has prepared it to be shipped out, after completing all required tests.

\subsubsection{Electric and Magnetic Assays}

Table 7 presents a rough estimate of the costs to realize the electric and magnetic assays listed in Section 4.4.3.5. The cost presented is an estimate for the realization of assays in one flow meter and do not encompass shipping or importation expenses.

Table 7: Electric and magnetic assays cost estimate.

\begin{tabular}{lc} 
Assay & Rough cost \\
\hline Electric and magnetic & 2300 USD \\
\hline
\end{tabular}

\subsubsection{Mechanical Assays}

Table 8 presents a rough estimate of the costs to realize the mechanical assays listed in Section 4.4.3.6. The cost presented is an estimate for the realization of assays in one flow meter and do not encompass shipping or importation expenses.

Table 8: Mechanical assays cost estimate.

\begin{tabular}{ll} 
Assay & Rough cost \\
\hline Mechanical & 2000 USD \\
\hline
\end{tabular}

The estimated term to complete the mechanical assays for one meter is about 2 days. This period of time begins when the meter is received by the laboratory and lasts until it has been prepared to be shipped out, after all required tests have been concluded.

\subsection{Importation}

Neither of the costs estimates presented so far encompass importation expenses.

It is worth noticing that the ideal scenario would be that the equipment to be type approved were already nationalized in Brazil and owned by the entity that wishes to do the certification when the process starts. However, if the material/equipment subject to certification is of foreign origin and there is no intention of purchase by such entity, there is the possibility of using the regime of temporary admission of the goods with the total suspension of the payment of taxes. Once the process is approved by the Federal Revenue Service (RFB), the term of validity of the scheme will be six months, automatically extendable for a further six months at the end of which the good must be returned to the 
Table 9: Rough estimate of cost for an ATM process for a family of liquid ultra-sonic flow meters

\begin{tabular}{llllll} 
Item & Unit of cost & Unit Cost & Quantity & Total Cost & Remarks \\
\hline Free translation & 1 Page & 7 USD & 100 & 700 USD \\
Certified translation & 1 Page & 35 USD & 100 & 3500 USD \\
Inmetro & 1 Man-hour & 90 USD & 116 & 10440 USD \\
Visual Inspection & 1 Man-hour & 90 USD & 12 & 1080 USD \\
Dimensional verification & 1 Man-hour & 90 USD & 16 & 1440 USD \\
Performance assay & 1 meter & 15000 USD & 2 & 30000 USD \\
Climatic assay & 1 meter & 6000 USD & 2 & 12000 USD & 4600 USD \\
Electric assay & 1 meter & 2300 USD & 2 & 4000 USD & NOT CONSIDERED \\
Mechanical assay & 1 meter & 2000 USD & 2 & & NOT CONSIDERED \\
Assay witnessing by Inmetro & & & & 67760 USD & NOT CONSIDERED \\
Shipping and importation & & & & & \\
Certification consultancy & & & & & \\
\hline Total Cost & & & &
\end{tabular}

exporter. For correct framing in this regime and attending the legal demands, one should see [18].

\subsection{Certification Consultancy}

If the applicant is an international company with no establishment in Brazil, it might be good to have assistance in monitoring and coordinating the type approval process until the approval ruling is published. Such consultancy would help on the following: Monitoring of Inmetro's requisitions and aid to the applicant on their fulfilment; Monitoring of requisitions and deadlines; Documents verification; Monitoring of subcontracted activities, such as document translations, and assays realization.

In this work no cost associated with a certification consultancy is considered. Although it may be significant, it is not obligatory.

\subsection{Total Cost}

As an example, the total cost associated with an ATM request for a family of ultra- sonic liquid flowmeters is presented in Table 9. The following assumptions are considered:
1. There would be the need to test in Brazil two meters with different diameters;

2. There would be no need of assay witnessing by Inmetro's technicians;

3. No costs associated with shipping and importation are considered;

4. No certification consultancy is considered;

\section{Final Considerations}

This work has presented the general guidelines related to the Brazilian type approval request and evaluation of an instrument, aiming to outline the main criteria and difficulties of the process, as well as to provide a rough idea of the cost involved. The main directives from applicable current regulation were pointed out and details were provided based on their 
evaluation and on the analysis of recent type approval rulings published by Inmetro.

A hypothetical family of flow meters to be applicable in the measurement of petroleum and its derivatives as well as anhydrous and hydrated alcohol was considered to exemplify the requirements, costs and terms of an ATM process. The information here provided may be used as a quick reference to possible applicants that could easiness the evaluation effort of proceeding with an ATM request.

\section{Acknowledgements}

Part of this work came as a result of a consultancy realized to BRA Certificadora which also involved some fruitfull discussions with Inmetro. I would like to thank both of them for their support.

\section{References}

[1] Instituto Nacional de Metrologia Qualidade e Tecnologia (INMETRO), Metrologia Legal. jun. 2017. [Online]. Available:

http://www.inmetro.gov.br/metlegal/ind ex.asp

[2] Conselho Nacional de Metrologia Normalização e Qualidade Industrial (CONMETRO), Resolução no 11, de 12 out. 1988, 1988.

\section{[3] International Organization of Legal Metrology (OIML), [Online]. Available: www.oiml.org.}

[4] AZEREDO, R. N. d. Avaliação da qualidade do serviço de apreciação técnica de modelo sob o ponto de vista do cliente utilizando a escala servqual. Dissertação de Mestrado [119 p.]. Mestrado em Sistemas de Gestão, Universidade Federal Fluminense. Niterói: UFF, 2009.

[5] Instituto Nacional de Metrologia Qualidade e Tecnologia. Diretrizes para apreciação técnica de modelo. Brasília: IMETRO, 2015.
[6] Portaria No. 484 de 07 dez. 2010. Brasília: IMETRO, 2010.

[7] Portaria No. 064 de 11 abr. 2003. Brasília: IMETRO, 2003.

[8] FOR-DIMEL-207 Termo de compromisso para aprovação de modelo. Brasília: IMETRO, 2015.

[9] FORDIMEL-038 Informações Complementares à Solicitação de Aprovação de Modelo. Brasília: IMETRO, 2015.

[10] MOD-DIMEL-037 Modelo para Desenhos Complementares à Solicitação de Aprovação de Modelo. Brasília: IMETRO, 2015.

[11] Administrative Ruling N. 049. Brasília: IMETRO, 2011.

[12] BRASIL. Lei no. 12.249, 11 de junho de 2010. Brasília: Casa Civil Subchefia para Assuntos Jurídicos, 2010.

[13] de Acreditação (Cgcre). [Online]. Available:

http://www.inmetro.gov.br/credenciame nto/index.asp

[14] Agência Nacional do Petróleo (ANP) e Instituto Nacional de Metrologia, Qualidade e Metrologia (INMETRO), Resolução Conjunta ANP/Inmetro n.1. 2013.

[15] International Organization of Legal Metrology (OIML), International Recommendation 117 - Dynamic measuring systems for liquids other than water, 2007.

[16] International Electrotechnical Commission (IEC), [Online]. Available: www.iec.ch

[17] Instituto Nacional de Metrologia, Qualidade e Tecnologia (INMETRO), Apreciação Técnica de Modelo. [Online]. Available: 
http://rweb01s.inmetro.gov.br/metlegal/i nstrumentosApreciacao.asp

[18] BRASIL. Instrução Normativa RFB No. 1600. Brasília: Receita Federal do Brasil (RFB), 2015. 